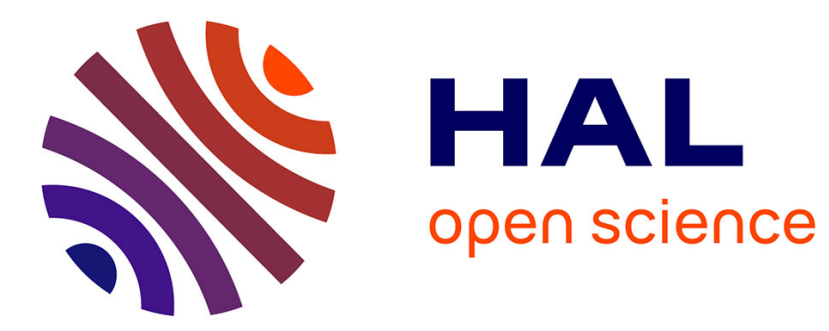

\title{
Investigation of DNA Condensing Properties of Amphiphilic Triblock Cationic Polymers by Atomic Force Microscopy
}

Nathalie Lidgi, Christine Guis, Blandine Brissault, Antoine Kichler, Christian Leborgne, Daniel Scherman, Sid Labdi, Patrick A. Curmi

\section{To cite this version:}

Nathalie Lidgi, Christine Guis, Blandine Brissault, Antoine Kichler, Christian Leborgne, et al.. Investigation of DNA Condensing Properties of Amphiphilic Triblock Cationic Polymers by Atomic Force Microscopy. Langmuir, 2010, 26 (22), pp.17552-17557. 10.1021/la103066c . hal-03151245

\author{
HAL Id: hal-03151245 \\ https://hal.science/hal-03151245
}

Submitted on 26 Feb 2021

HAL is a multi-disciplinary open access archive for the deposit and dissemination of scientific research documents, whether they are published or not. The documents may come from teaching and research institutions in France or abroad, or from public or private research centers.
L'archive ouverte pluridisciplinaire HAL, est destinée au dépôt et à la diffusion de documents scientifiques de niveau recherche, publiés ou non, émanant des établissements d'enseignement et de recherche français ou étrangers, des laboratoires publics ou privés. 


\section{Investigation of DNA condensing properties of}

\section{amphiphilic triblock cationic polymers by Atomic Force}

\section{Microscopy}

Nathalie Lidgi-Guigui $^{*}$, Christine Guis ${ }^{\ddagger}$, Blandine Brissault $^{+}$, Antoine Kichler $^{\text {}}$, Christian Leborgne ${ }^{*}$, Daniel Scherman ${ }^{\#}$ Sid Labdi ${ }^{*}$, Patrick A. Curmi*.

*Laboratoire Structure et Activité des Biomolécules Normales et Pathologiques, Université d'Evry-Vald'Essonne and INSERM U829, Evry, France;

${ }^{\ddagger}$ Laboratoire Analyse et Modélisation pour la Biologie et l'Environnement - UMR CNRS 8587, Université d'Evry-Val-d'Essonne, Evry, France;

${ }^{+}$Institut de Chimie et des Matériaux Paris-Est UMR 7182, Thiais, France;

†Généthon, Evry, France;

\# UMR 8151 CNRS-U1022 INSERM, Université René Descartes, Chimie Paristech, Paris, France;

${ }^{¥}$ Laboratoire des Milieux Nanostructurés, Université d'Evry-Val-d'Essonne, Evry, France.

Corresponding author: nathalie.lidgi-guigui@univ-evry.fr

RECEIVED DATE (to be automatically inserted after your manuscript is accepted if required according to the journal that you are submitting your paper to) 
ABSTRACT Introduction of nucleic acids into cells is an important biotechnology research field which also holds great promises for therapeutic applications. One of the key steps in the gene delivery process is compaction of DNA into nanometric particles. The study of DNA condensing properties of three linear cationic triblock copolymers poly(ethylenimine-b-propylene glycol-b-ethylenimine), namely LPEI50-PPG $36-\mathrm{LPEI}_{50}$, LPEI $19-\mathrm{PPG}_{36}-\mathrm{LPEI}_{19}$ and $\mathrm{LPEI}_{14}-\mathrm{PPG}_{68}-\mathrm{LPEI}_{14}$, indicates that proper DNA condensation is driven both by the charge and the size of the respective hydrophilic linear polyethylenimine (LPEI) and hydrophobic poly propylene glycol (PPG) parts. Atomic Force Microscopy was used to investigate the interactions of the triblock copolymers with plasmid DNA at the single molecule level and to enlighten the mechanism involved in DNA condensation.

KEYWORDS Atomic Force Microscopy, AFM, DNA, condensation, amphiphilic polymers 


\section{Introduction}

One key challenge for gene therapy is to find an efficient and safe way to introduce DNA into cells. To favor DNA transportation through the cellular membrane into the nucleus, various delivery systems have been developed. Different viral agents have been used to that end though they often induce adverse immune responses. An alternative to these biological vectors consists in developing synthetic carrier systems $^{1,2,3,4}$. Among the many compounds that have been synthesized, the polyethylenimines family (PEIs) attracted great attention due to its particularly high capacity to deliver DNA into cells ${ }^{3,5,6}$. However, though PEIs are able to deliver nucleic acids into various tissues $i n v i v{ }^{7}$, they were found to be devoid of activity for DNA transfer into muscle cells ${ }^{8}$. By contrast, neutral amphiphilic triblock copolymers such as Pluronic L64 (poly(ethylene glycol-b-propylene glycol-b-ethylene glycol): PEG$_{13-}$ $\left.\mathrm{PPG}_{30}-\mathrm{PEG}_{13}\right)$ which have been shown to be inefficient for in vitro DNA delivery in eukaryotic cells display, in vivo, a significant muscle transfection activity ${ }^{9,10}$. Furthermore, in aqueous media, the amphiphilic properties of Pluronics allow them to adopt a micellar structure which can be tuned to regulate the stability of the polyplexes formed and their distribution and fate in the body.

Based on these findings, it was of interest to attempt to combine the properties of both cationic PEIs and neutral Pluronics by synthesizing new amphiphilic cationic triblock polymers. For this purpose, three ABA copolymers poly(ethylenimine-b-propylene glycol-b-ethylenimine) were synthesized ${ }^{11}$ : LPEI I0-PPG ${ }_{36}-\mathrm{LPEI}_{50}, \mathrm{LPEI}_{19}-\mathrm{PPG}_{36}-\mathrm{LPEI}_{19}$ and $\mathrm{LPEI}_{14-}-\mathrm{PPG}_{68}-\mathrm{LPEI}_{14}$, where LPEI (i.e. Linear PEI) and PPG (i.e. polypropylene glycol) correspond respectively to the hydrophilic (A) and hydrophobic (B) parts (figure 1). These polymers differ by the length of their hydrophobic and hydrophilic moieties. The transfection efficiency of these three polymers was evaluated in vitro on a cultured human cell line and it was found that their efficiency greatly vary compared to the reference compound $22 \mathrm{kDa}$ linear PEI. In order to explore the molecular mechanisms responsible for these differences, we studied here the impact of these three copolymers on DNA condensation, the very first step of the transfection process. Agarose gel electrophoresis and dye exclusion assay provided information on the capability of these 
polymers to interact with DNA while Atomic Force Microscopy (AFM) helped us to further document the structure formed by these polymers alone or in the presence of plasmid DNA ${ }^{12,13}$.

\section{Experimental section}

2.1 Materials. The SMD2-Luc $\Delta$ ITR $(7.6 \mathrm{~kb})$ expression plasmid encodes the firefly luciferase gene under the control of the human cytomegalovirus (CMV) immediate-early promoter. The plasmid was amplified in E. coli using standard techniques. The DNA was then purified using anion-exchange resin (NucleoBond PC 2000 kit from Macherey-Nagel).

The detailed synthesis of the copolymers will be described elsewhere ${ }^{11}$. Briefly, the poly(ethylenimine-b-propylene glycol-b-ethylenimine) (LPEI-PPG-LPEI) triblock copolymers were prepared in two stages as follows: (i) synthesis of the poly(methyloxazoline-b-propylene glycol-bmethyloxazoline) (PMeOXZ-PPG-PMeOXZ) copolymers by cationic polymerization of 2-methyl-2oxazoline (MeOXZ) monomer using end difunctionalized polypropylene glycol homopolymer (PPG) either as macroinitiator or quenching reagent, (ii) subsequent acidic hydrolysis of the amide units present in PMeOXZ blocks to obtain the linear poly(ethylenimine) (LPEI) termini parts. The MeOXZ monomer and solvent were purified by distillation over calcium hydride. The PPG36-diTs macroinitiator was synthezised as previously described ${ }^{14}$ and the PPG68-diNH2 quenching reagent was used as received. The synthesis of the starting copolymers was achieved using PMeOXZ-PPG-PMeOXZ, 2methyl-2-oxazoline to react with the required $\mathrm{MeOXZ} /$ initiator feed ratio in $\mathrm{AcN}$ at $80^{\circ} \mathrm{C}$ until complete monomer conversion. After evaporation of solvent and purification procedure, the chemical structure and composition of the purified compounds were characterized by ${ }^{1} \mathrm{H}$ nuclear magnetic resonance spectrocopy, size exclusion chromatography and thermogravimetric analysis.

In the next step, PMeOXZ-PPG-PMeOXZ copolymers were dissolved in aqueous hydrochloric medium and the reaction mixture was left for $4 \mathrm{~h}$ refluxing for complete amide moieties hydrolysis. The LPEI-PPG-LPEI copolymers obtained, being water soluble in their hydrochloric salt form, were then 
neutralized with sodium hydroxide, which lead to the precipitation of the neutral LPEI-PPG-LPEI triblock copolymers as a brown solid, which was filtered, washed with water and dried in vacuo. The triblock structure, composition and molar mass of the three copolymers were determined from NMR spectroscopy (Mn LPEI ${ }_{50}-\mathrm{PPG}_{36}-\mathrm{LPEI}_{50}=6300 \mathrm{~g} / \mathrm{mol}, \mathrm{Mn} \mathrm{LPEI}_{19}-\mathrm{PPG}_{36}-\mathrm{LPEI}_{19}=3700 \mathrm{~g} / \mathrm{mol}, \mathrm{Mn}$ $\left.\mathrm{LPEI}_{14}-\mathrm{PPG} 68-\mathrm{LPEI}_{14}=5200 \mathrm{~g} / \mathrm{mol}\right)$.

2.2. Transfection experiments. Human hepatocarcinoma cells (HepG2 cells; American Type Culture Collection) were cultured in Dulbecco's modified Eagle medium (DMEM; Gibco-BRL) supplemented with 2 mM L-glutamine and 10\% of fetal calf serum (FCS; HyClone). Briefly, 280,000 HepG2 cells were plated in 24-well plates (Costar) one day before transfection. The desired amount of polymer and 4 $\mu \mathrm{g}$ of plasmid DNA were diluted each in $100 \mu \mathrm{l}$ of $150 \mathrm{mM} \mathrm{NaCl}$ and gently mixed. DNA complexes were generated by using varying polymer/DNA weight ratios (between 1/4 and 60/4). After 15 min incubation the poymer/DNA mixture was diluted with serum-free medium to a final volume of $1 \mathrm{ml} .0 .5$ $\mathrm{ml}$ of the transfection mix was then added to HepG2 well of the duplicate. After $3 \mathrm{~h}$ incubation at $37^{\circ} \mathrm{C}$, the medium was replaced with fresh medium containing 10\% FCS. Luciferase activity was assayed 28 hours after transfection. Each experiment was performed in duplicate. The transfection efficiency is expressed as light units / $10 \mathrm{~s} / \mathrm{mg}$ protein and the reported values are the means of the duplicates.

2.3 Electrophoresis mobility shift assay (EMSA). Interaction of the copolymer with DNA was studied by means of gel retardation assays. $1 \mu \mathrm{g}$ plasmid DNA and respectively $0.125 \mu \mathrm{g}, 0.25 \mu \mathrm{g}$, $0.5 \mu \mathrm{g}, 0.75 \mu \mathrm{g}, 1 \mu \mathrm{g}, 2 \mu \mathrm{g}, 2.5 \mu \mathrm{g}, 5 \mu \mathrm{g}, 10 \mu \mathrm{g}$ and $15 \mu \mathrm{g}$ of copolymer were each diluted in $25 \mu \mathrm{l}$ of 150 $\mathrm{mM} \mathrm{NaCl}$ and mixed. After a period of $20 \mathrm{~min}$, samples $(20 \mu \mathrm{l})$ were electrophorezed on $1 \%$ agarose gels in Tris-borate-EDTA buffer and DNA was visualized after SYBR Safe staining.

2.4 Determination of the accessibility of DNA in polyplexes. The efficiency of DNA complexation mediated by the polymers was examined using a fluorescence quenching assay based on the use of SYBR Safe, a DNA-intercalating agent. Fluorescence of SYBR Safe is significantly enhanced upon DNA binding and quenched when displaced by higher affinity compounds. $2 \mu \mathrm{g}$ DNA were added to increasing amount of copolymer. After $20 \mathrm{~min}, 100 \mu \mathrm{l}$ of the resulting complexes were added to $100 \mu \mathrm{l}$ 
of $150 \mathrm{mM} \mathrm{NaCl}$ in water containing SYBR Safe (diluted 2000 times in water). The fluorescence ( $\lambda$ exc $=490 \mathrm{~nm}$ and $\lambda \mathrm{em}=510 / 570 \mathrm{~nm}$ ) is reported relative to the value obtained in the absence of the polymer after subtraction of the fluorescence obtained with SYBR Safe alone.

\subsection{AFM Imaging}

2.5.1. Preparation of mica sheets: Muscovite mica was used as a substrate for all AFM observations Pretreatment of mica was necessary to promote electrostatic immobilization between the condensates and mica $^{15}$ it was thus prepared as follows: $20 \mu \mathrm{l}$ of a $10 \mathrm{mM} \mathrm{NiCl}_{2}$ solution in water was deposited onto the surface of freshly cleaved mica for $1 \mathrm{~min}$. The mica was then thoroughly rinsed with pure water (18.2 M $\Omega . c m$ resistivity, MilliQ, Millipore) and dried with a filter paper to prevent the formation of salt crystals on the surface.

2.5.2. Preparation of Polymer-DNA Complexes:Plasmid DNA was first imaged in the absence of polymer. A $2 \mathrm{mg} \cdot \mathrm{ml}^{-1}$ in water stock solution was further diluted to $0.4 \mu \mathrm{g} \cdot \mathrm{ml}^{-1}$ in $5 \mathrm{mM} \mathrm{MgCl}_{2} .7 \mu \mathrm{lof}$ this solution were spotted onto $\mathrm{NiCl}_{2}$ pretreated mica and incubated for 1 min after which the mica sheet was thoroughly rinsed with $0.02 \%$ diluted uranyl acetate and then dried with a filter paper. Similarly, the three polymer solutions at $2 \mathrm{mg} \cdot \mathrm{ml}^{-1}$ in water were further diluted to $0.4 \mu \mathrm{g} \cdot \mathrm{ml}^{-1}$ in water for AFM observation either free from DNA or after mixing with DNA. Solution with polymer/DNA ratios of 1/8, $1 / 4,1 / 1$ and $4 / 1$ were obtained this way. $7 \mu$ of the resulting solutions were spotted on pretreated mica sheets. The samples were thoroughly rinsed with $0.02 \%$ diluted uranyl acetate and dried with a filter paper.

2.5.3. AFM imaging. A Nanoscope IIIa AFM (Veeco Instrument) was used for imaging in tapping mode with silicon cantilevers OTESPA (Veeco). The scan frequency was typically $1.5 \mathrm{~Hz}$, and the modulation amplitude was approximately 1V. All samples were imaged in air.

\section{Results}


3.1 Transfection efficiency. As shown on figure 2, LPEI50-PPG $36-\mathrm{LPEI}_{50}$ displays a slightly higher transfection efficiency than the $22 \mathrm{kDa}$ linear PEI reference polymer. Interestingly, we observed that the efficiency for transfection is almost completely lost when the hydrophobic PPG block is enlarged together with a reduction of the hydrophilic LPEI block like in the LPEI $_{14}-\mathrm{PPG}_{68}-\mathrm{LPEI}_{14}$ polymer. On the other hand, the polymer $\mathrm{LPEI}_{19}-\mathrm{PPG}_{36}-\mathrm{LPEI}_{19}$ which presents an intermediate structure between these two polymers possesses a well conserved transfection capability.

\subsection{Probing the interaction of DNA with the triblock copolymers.}

Electrophoresis mobility shift assay (EMSA) was used to quantify the interaction of the LPEI50-

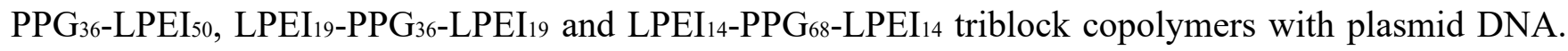
The accessibility of DNA in the formed polyplexes was probed by fluorimetry.

EMSA (figure 3a) allows to determine the threshold concentration from which copolymer inhibit DNA migration. As shown in figure 3a, LPEI50-PPG 36 -LPEI50 efficiently retards DNA from a polymer/DNA weight ratio of 3/4. LPEI $19-\mathrm{PPG}_{36}-\mathrm{LPEI}_{19}$ interacted very efficiently with plasmid DNA as well since DNA retardation was almost complete at a weight ratio of $1 / 1$. In contrast, $\mathrm{LPEI}_{14-\mathrm{PPG}_{68-}}$ LPEI $_{14}$ was unable to retard DNA even at the highest weight ratio tested (15/1). Interestingly, the gel mobility shift assay with both $\mathrm{LPEI}_{50}-\mathrm{PPG}_{36}-\mathrm{LPEI}_{50}$ and $\mathrm{LPEI}_{19}-\mathrm{PPG}_{36}-\mathrm{LPEI}_{19}$ showed that from a weight ratio of 2/1 and above, fluorescent material migrates toward the cathode while $\mathrm{LPEI}_{14-} \mathrm{PPG}_{68-}$ LPEI $_{14}$ presents migrating material both toward the anode (as standard DNA migration) and the cathode from a weight ratio of $5 / 1$. These behaviors most probably reflect an inversion of the global electric charge of the complexes formed as discussed below (see discussion).

Variation of the fluorescence intensity of SYBR Safe was used to probe the accessibility of DNA in DNA-polymer complexes. This assay consists in mixing a constant amount of DNA with increasing amounts of polymer. SYBR Safe is then added to the mixture and its fluorescence emission increases once it is intercalated in the DNA molecule. As shown in figure $3 b$, the results obtained with LPEI50-

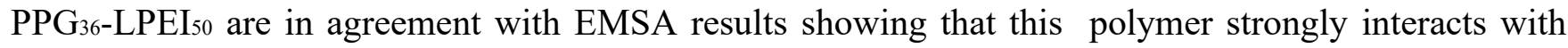
DNA since the SYBR Safe fluorescence rapidly decreases when the amount of copolymer increases. 
Fluorescence decreases to about $15 \%$ its initial value for a polymer/DNA weight ratio of $3 / 4$. As observed with EMSA, the tribloc copolymer $\mathrm{LPEI}_{19}-\mathrm{PPG}_{36}-\mathrm{LPEI}_{19}$ also appears very efficient to bury DNA as SYBR Safe fluorescence again rapidly decreases sharply when the amount of copolymer increases. In contrast, the presence of $\mathrm{LPEI}_{14-}-\mathrm{PPG}_{68}-\mathrm{LPEI}_{14}$ did not change significantly the fluorescence emission of SYBR Safe up to a weight ratio of 8 which probably reflects its poor capability to complex with DNA. For a weight ratio of $16 / 1$, the fluorescence was still above $50 \%$ of the initial signal.

\subsection{AFM imaging.}

AFM imaging was used to document the molecular structures formed by the triblock polymers and their impacts of DNA conformation and supramolecular organization.

3.3.1. Naked DNA: AFM imaging was first performed on plasmid DNA in the absence of condensing reagent. Double stranded DNA is clearly visible on the substrate which appears homogeneously flat (figure 4). DNA molecules form closed loops displaying twists of the strands characteristic of uncondensed DNA ${ }^{16}$. Apparent height and width of these DNA molecules was measured at $1.2 \mathrm{~nm}$ and $23 \mathrm{~nm}$ respectively. Molecules with similar geometries decorate the entire substrate.

3.3.2. Copolymers: AFM images of aqueous solution of $\mathrm{LPEI}_{50}-\mathrm{PPG}_{36}-\mathrm{LPEI}_{50}, \mathrm{LPEI}_{19}-\mathrm{PPG}_{36}-\mathrm{LPEI}_{19}$ and $\mathrm{LPEI}_{14}-\mathrm{PPG}_{68}-\mathrm{LPEI}_{14}$ are presented on figure 5. All the copolymers generated similar structures which appear as assemblies of nanoparticles. These results clearly indicate a self-organization propensity of these polymers. It is interesting to note that images of Figure 5 were obtained with a polymer concentration of $20 \mathrm{ng} 3 \mathrm{~mL}-1$ for LPEI50-PPG36-LPEI50 and $40 \mathrm{ng} 3 \mathrm{~mL}-1$ for the two other copolymers (i.e., the same concentration as the one used when the polymer is mixed with DNA). This choice has been made because very few patterns are observed for LPEI50-PPG36-LPEI50 at $40 \mathrm{ng}$ 3mL-1 (data not shown). The amount of the nanoparticle assemblies as well as their extent are dependent on the polymer solution concentration. The fact that only a part of Figure $5 \mathrm{c}$ is decorated with nanoparticles of LPEI14-PPG68-LPEI14 is a consequence of this phenomenon. However, polymersurface interactions cannot be neglected and may also influence the size and shape of these nanoparticle assemblies. 
3.3.3. LPEI50-PPG36-LPEI50 / DNA solutions: Figure 6 shows AFM images of samples generated by mixing a constant amount of plasmid DNA with increasing amounts of LPEI50-PPG $56-\mathrm{LPEI}_{50}$. Two main kinds of structures are visible on these images: flower-like structures and large aggregates. The flower-like arrangements possess a very high core surrounded by a shell of filaments which have similar height and width than the naked plasmid DNA shown on figure 4. The flower-like structures are plasmid DNA in the process of condensing as better seen on the insets. Figure 6a shows that several plasmid molecules are brought together as the process starts. When the polymer/DNA weight ratio increases from $1 / 8$ to $1 / 1$ (figure $6 a$ to $6 \mathrm{c}$ ), the filamentous shell shrinks onto the core, the number of flower like structures decreases with a parallel increase of the number of large aggregates. This behavior suggests that the large aggregates represent completely condensed plasmid DNA. For figure 6d, the polymer weight exceeds the DNA weight (4/1) and very large and high aggregates are seen, however, one still observes DNA in the process of condensing. interestingly, the first three weight ratios of polymer/DNA investigated here $(1 / 8,1 / 4$ and $1 / 1)$ are much lower than the one used for gene delivery while the latter (i.e. 4/1 weight ratio) was shown to be efficient for transfection (figure 2).

3.3.4- LPEI19-PPG36-LPEI19/DNA solutions : Figure 7 presents the results of similar experiment conducted with LPEI $19-\mathrm{PPG}_{36}-\mathrm{LPEI}_{19}$. The background roughness seen of figure $7 \mathrm{a}$ is flattened as the polymer concentration increases. This behavior was already noticed with this polymer alone. Furthermore, the background structure seen on figure $7 \mathrm{a}$ has a very similar morphology than that presented on figure $5 \mathrm{~b}$, the background is thus assumed to be a polymer matrix. Onto this rough background, plasmids DNA are visible and display similar shapes and sizes than observed on figure 4 with plasmid DNA alone. On figure $7 \mathrm{~b}$, the condensation process has clearly started as demonstrated by the presence of flower-like structures. However, the thickness of the filament shell is larger than that seen with LPEI50-PPG36-LPEI50. For a weight ratio of 1/1 (figure 7c), bigger structures are observed where several plasmid DNA are brought together as found on figure 6a. Eventually, figure 7d displays objects which appar as intermediates between those observed on figure $6 \mathrm{a}$ and $6 \mathrm{~b}$ : aggregates and 
flower-like structure with higher core and a filament shell of smaller diameter than seen on figure $7 \mathrm{~b}$ and $7 \mathrm{c}$.

-LPEI $14-{ }_{1}$ PG $_{6}-\mathrm{LPEI}_{14} / \mathrm{DNA}$ solutions: Similar experiments were performed using the most hydrophobic and least cationic polymer LPEI $14-\mathrm{PPG}_{68}-\mathrm{LPEI}_{14}$. As shown in figure 8 two main kinds of structures are formed: DNA strands and nanoparticles assemblies. No flower-like arrangements such as those observed with the two other polymers are visible even at the highest weight ratio. The sizes and shapes of the DNA strands are very similar to naked DNA control (figure 4). Nanoparticles assemblies are visible at low polymer concentration and their presence decrease when the polymer/DNA weight ratio increases, they completely disappear at the highest polymer concentration (figure 8d). These nanoparticles assemblies are very similar to those observed on figure 5 and follow the same behavior as the polymer concentration increase in the solution.

\section{Discussion.}

EMSA and fluorescence assays demonstrate that the three polymers interact in a very different manner with DNA. LPEI $50-\mathrm{PPG}_{36}-\mathrm{LPEI}_{50}$ and $\mathrm{LPEI}_{19}-\mathrm{PPG}_{36}-\mathrm{LPEI}_{19}$ are able to retard significantly DNA migration at a weight ratio of $3 / 4$ and $1 / 1$ respectively, whereas LPEI $_{14-P P G}$ - 8 -LPEI 14 cannot retard DNA even at the highest weight ratio tested (15/1). It is worthy to note that some material migrates toward the cathode for the highest polymer weight ratios. Material migrating in such direction can only be positively charged self-assembled polymer since polymer/DNA polyplexes are too large to migrate in the gel. This result also suggests that SYBR Safe is included into self-organized polymers (it is known that the fluorescence of SYBR Safe increases when this agent moves into an hydrophobic environment $\left.{ }^{17}\right)$.

Interestingly, the fluorescence results are in good agreement with EMSA data and indicate that $\mathrm{LPEI}_{50}-\mathrm{PPG}_{36}-\mathrm{LPEI}_{50}$ and $\mathrm{LPEI}_{19}-\mathrm{PPG}_{36}-\mathrm{LPEI}_{19}$ may behave as true DNA condensing agents while LPEI $_{14-P P G}{ }_{68}-\mathrm{LPEI}_{14}$ seems unable to do it. The small increase in fluorescence observed for the lowest 
weight ratios with this last compound may be explained by the fact that the polymer and the SYBR Safe form a fluorescent complex as indicated above.

The EMSA and the DNA accessibility assays thus point out differences of behavior between the three triblock polymers in their interaction with DNA. Atomic force microscopy was used to access to detailed information on the putative process of DNA condensation triggered by some of these polymers. The AFM study shows a step by step condensation of DNA with LPEI $50-\mathrm{PPG}_{36}-\mathrm{LPEI}_{50}$ and $\mathrm{LPEI}_{19-}$ ${\text { PPG } 36-L_{1}}_{19}$ copolymers starting respectively at a weight ratio of $1 / 8$ and $1 / 4$. In contrast, no interactions between DNA and the copolymer LPEI $14-\mathrm{PPG}_{68}-\mathrm{LPEI}_{14}$ could be observed by this technique.

To explain the different behaviors observed for these polymers, one has to consider the conditions which have to be fulfilled to condense DNA. The first essential step is to overcome the coulombian potential arising from the negatively charged phosphates along the DNA strands. As the Manning's counterion condensation theory ${ }^{18}$ suggests, polymer remains unable to condense DNA until the neutralization of a critical amount of negative charges on DNA. Wilson and Bloomfield have calculated that to condense DNA, only $90 \%$ of the $\mathrm{P}^{-}$have to be neutralized when the condensing agent used is spermine or spermidine ${ }^{20}$. In the case of LPEI $50-\mathrm{PPG}_{36}-\mathrm{LPEI}_{50}$ (figure 6), the N/P ratios were $1 / 2,1 / 1$ and $4 / 1$ at weight ratio of $1 / 8,1 / 4$ and $1 / 1$ respectively (this calculation is based on the fact that in $22 \mathrm{kDa}$ LPEI, $75 \%$ of the amino groups are protonated at physiological $\mathrm{pH}^{19}$ and that the $\mathrm{pKa}$ of the PEI parts of the copolymers studied here is identical to that of LPEI. The same calculation made with LPEI $_{19}-\mathrm{PPG}_{36-}$ $\mathrm{LPEI}_{19}$ (figure 7), gives a N/P ratio of more than one thousand at weight ratio of $4 / 1$, yet the condensation process is still going on. Unexpectedly, the triblock copolymer LPEI $14-\mathrm{PPG}_{68}-\mathrm{LPEI}_{14} \mathrm{Was}$ completely unable to condense DNA although it carries positively charged nitrogens.

This apparent difference between the present results and that published by Wilson and Bloomfield may be explained by differences of the copolymer conformation. Indeed, when amphiphilic polycationic polymers are used in aqueous media, the chains tend either to shrink their hydrophobic blocks and/or to self-organized into particles. This behavior is accompagnied by the burying of some (or all) of the 
positive charges into the hydrophobic environment, which thus diminishes the DNA's condensing potential of the carrier.

The presence of nanoparticles assemblies on AFM images obtained in absence or presence of DNA is in good agreement with this hypothesis. Indeed, such nanoparticles observed in the presence of DNA show similarities (morphology and behavior with the polymer concentration) with that observed on figure 5 which indicates that they are most likely formed by the self-assembled polymers. Ina striking example (LPEI $\left.{ }_{19}-\mathrm{PPG}_{36}-\mathrm{LPEI}_{19}\right)$ for the lowest weight ratio, nanoparticles assemblies are visible while DNA remains uncondensed. In these conditions, given $\mathrm{N} / \mathrm{P} \sim 1 / 3$, one expects either that the condensation process starts or at least that all the polymer molecules are in interaction with DNA. However, bare DNA is visible together with nanoparticles of polymer (figure 7a). This result suggests that the polymer adopts such a micellar structure that all the positively charged nitrogens are buried. $\mathrm{LPEI}_{14-}-\mathrm{PPG}_{68}-\mathrm{LPEI}_{14}$ behaves in a similar way from the lowest weight ratio. On the opposite, LPEI50$\mathrm{PPG}_{36}-\mathrm{LPEI}_{50}$ which carries long LPEI chains most probably always keep some of the $\mathrm{N}^{+}$available for interaction with partners as DNA even if the polymer is arranged into micelles.

With $\mathrm{LPEI}_{19}-\mathrm{PPG}_{36}-\mathrm{LPEI}_{19}$ and $\mathrm{LPEI}_{14}-\mathrm{PPG}_{68}-\mathrm{LPEI}_{14}$, when the polymer proportion increases, less and less of the nanoparticle's assemblies are observed (figures 7 and 8). The condensation process starts with the less hydrophobic polymer $\mathrm{LPEI}_{19}-\mathrm{PPG}_{36}-\mathrm{LPEI}_{19}$ (Figure 7b) but fails with the most hydrophobic one, $\mathrm{LPEI}_{14-}-\mathrm{PPG}_{68}-\mathrm{LPEI}_{14}$. With more molecules, $\mathrm{LPEI}_{19}-\mathrm{PPG}_{36}-\mathrm{LPEI}_{19}$ adopts a micellar conformation where $\mathrm{N}^{+}$are available for interaction with DNA. Taking into account the longer size of the hydrophobic PPG central block of LPEI ${ }_{14}-\mathrm{PPG}_{68}-\mathrm{LPEI}_{14}$, all the positive charges may be masked in this case. This in turn hinders efficient electrostatic interactions with the plasmid DNA.

Together these data suggest that the presence in the polymer of available positively charged nitrogenis a sine qua non condition to neutralize DNA. When this first step is completed, the hydrophobic PPG block must still be kept from contact with water to incorporate more DNA molecules. Since the polyplex is formed, a new micellar structure is adopted by LPEI50-PPG $36-\mathrm{LPEI}_{50}$ and $\mathrm{LPEI}_{19}-\mathrm{PPG}_{36}$ - 
LPEI$_{19}$ carrying the plasmid DNA. After the DNA neutralization step, the condensation process appears thus to be guided by changes of the micellar structure.

\section{Conclusion}

We studied here by different means the DNA condensing properties of three amphiphilic cationic triblock copolymers which contain varying hydrophilic-charged and hydrophobic part. AFM helped us to enlighten the mechanisms underlying the variations of the cell transfection efficiency and DNA interaction properties of these three polymers. Together the results point out the importance of a balanced content of the hydrophilic-charged and hydrophobic part for both DNA condensation and cell transfection efficiency. They also provide information for a better understanding of the successive DNA compaction steps which are of crucial importance to develop better synthetic DNA vectors.

ACKNOWLEDGMENT We thank P. Aubert (University Paris Sud) for helpful suggestions and discussions. 
Figure Captions.

Figure 1: Structure of the cationic triblock polymers investigated here (a) LPEI50-PGG36-LPEI50 (b) $\mathrm{LPEI}_{19}-\mathrm{PGG}_{36}-\mathrm{LPEI}_{19}$ and (c) LPEI $14-\mathrm{PGG}_{68}-\mathrm{LPEI}_{14}$.

Figure 2: Transfection efficiency of the LPEI50-PGG $36-\mathrm{LPEI}_{50}, \mathrm{LPEI}_{19}-\mathrm{PGG}_{36}-\mathrm{LPEI}_{19}$ and LPEI ${ }_{14-} \mathrm{PGG}_{68}-$ $\mathrm{LPEI}_{14}$ polymers. The efficiency of $22 \mathrm{kDa}$ LPEI is given as a reference control. For each polymer, only the condition which resulted in the highest transfection efficiency is shown (donner ces valeurs).

Figure 3: (a) EMSA: top LPEI $50-\mathrm{PGG}_{36}-\mathrm{LPEI}_{50}$, middle $\mathrm{LPEI}_{19}-\mathrm{PGG}_{36}-\mathrm{LPEI}_{19}$ and bottom $\mathrm{LPEI}_{14-}$ PGG68-LPEI 14. Number above each lane refers to the polymer/DNA weight ratio. (b) Accessibility of DNA in polyplexes.

Figure 4: AFM images of Plasmid DNA $(0.4 \mu \mathrm{g} / \mathrm{ml})$ on $\mathrm{NiCl}_{2}$ pretreated mica.

Figure 5: AFM images of (a) LPEI50-PGG $36-\mathrm{LPEI}_{50}(20 \mathrm{ng} / \mathrm{ml})$, (b) LPEI $19-\mathrm{PGG}_{36}-\mathrm{LPEI}_{19}(40 \mathrm{ng} / \mathrm{ml})$ and (c) $\mathrm{LPEI}_{14}-\mathrm{PGG}_{68}-\mathrm{LPEI}_{14}(40 \mathrm{ng} / \mathrm{ml})$ on $\mathrm{NiCl}_{2}$ pretreated mica.

Figure 6: AFM images of $\mathrm{LPEI}_{50}-\mathrm{PGG}_{36}-\mathrm{LPEI}_{50} / \mathrm{DNA}$ mixtures on $\mathrm{NiCl}_{2}$ pretreated mica at weight ratios of (a) $1 / 8$, (b) $1 / 4$, (c) $1 / 1$ and (d) $4 / 1$.

Figure 7: AFM images of $\mathrm{LPEI}_{19}-\mathrm{PGG}_{36}-\mathrm{LPEI}_{19}$ / DNA mixtures on $\mathrm{NiCl}_{2}$ pretreated mica at weight ratios of (a) $1 / 8$, (b) $1 / 4$, (c) $1 / 1$ and (d) $4 / 1$.

Figure 8: AFM images of $\mathrm{LPEI}_{14}-\mathrm{PGG}_{68}-\mathrm{LPEI}_{14}$ / DNA mixtures on $\mathrm{NiCl}_{2}$ pretreated mica at weight ratios of (a) $1 / 8$, (b) $1 / 4$, (c) $1 / 1$ and (d) $4 / 1$. 
(a)

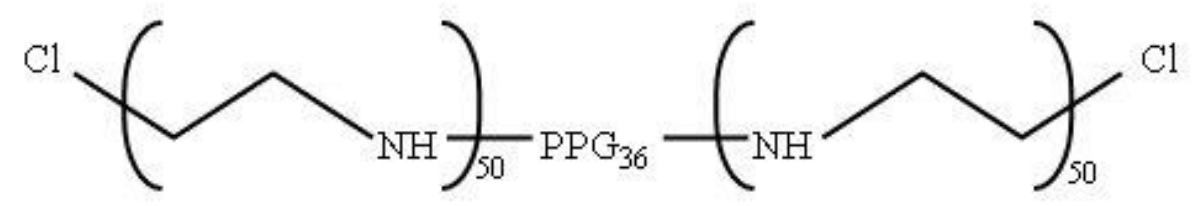

(b)

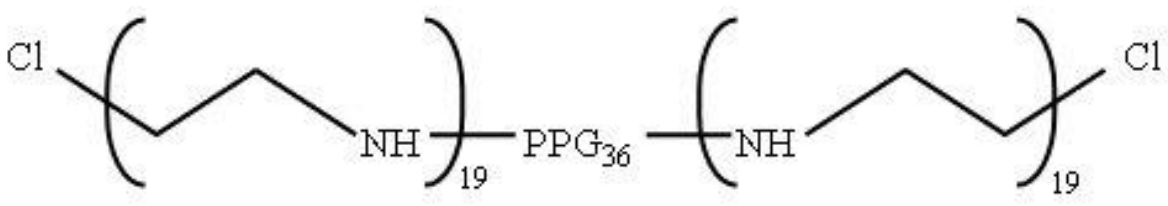

(c)

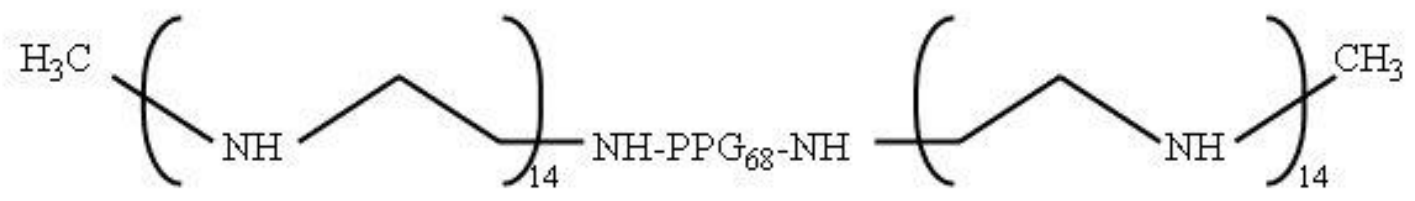

Figure1

$$
\mathrm{PPG}_{\mathrm{n}}=-\left(\mathrm{CH}_{2}-\mathrm{CH}\left(\mathrm{CH}_{3}\right)-\mathrm{O}\right)_{\mathrm{n}^{-}}
$$


Figure 2

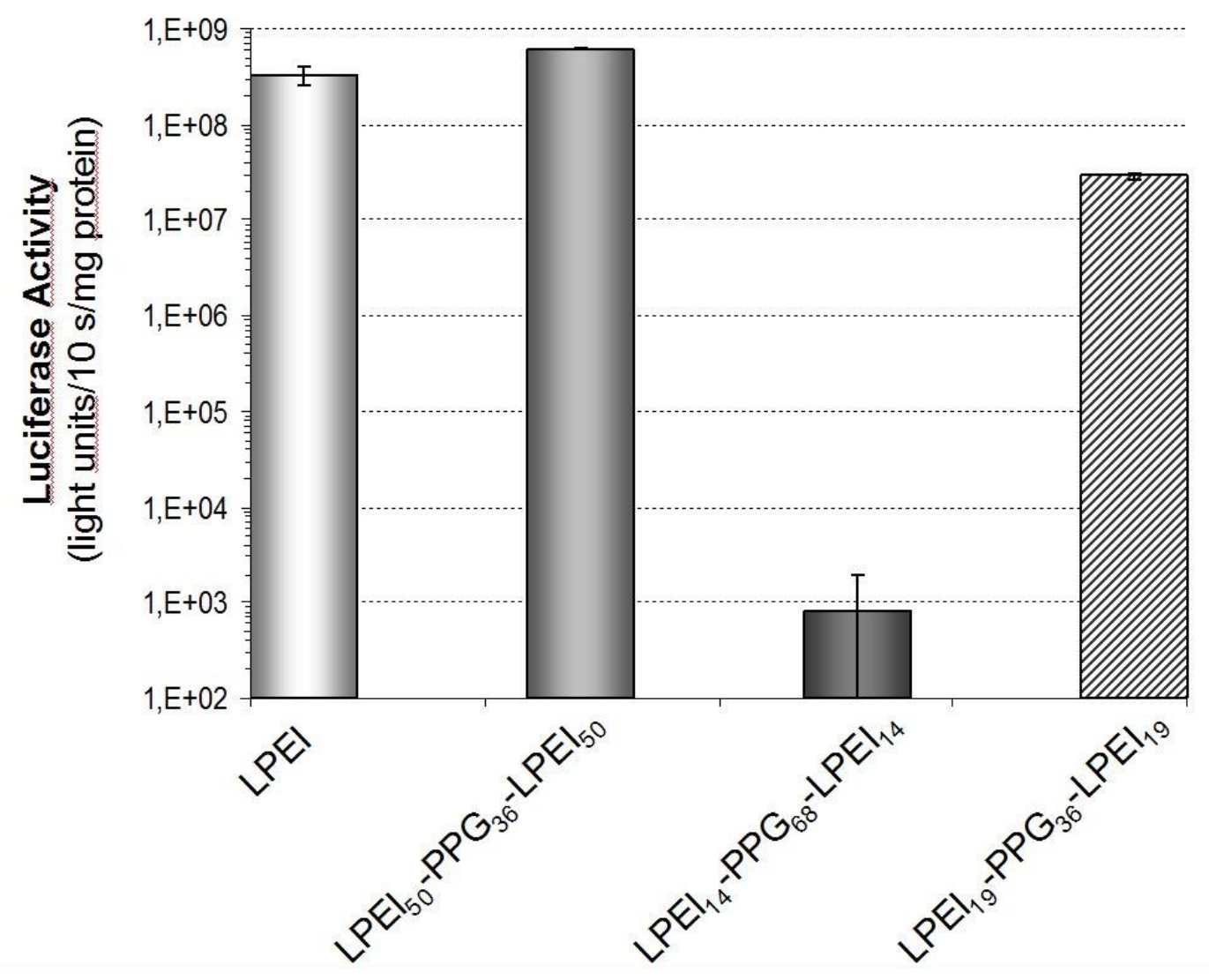


Figure 3

(a)
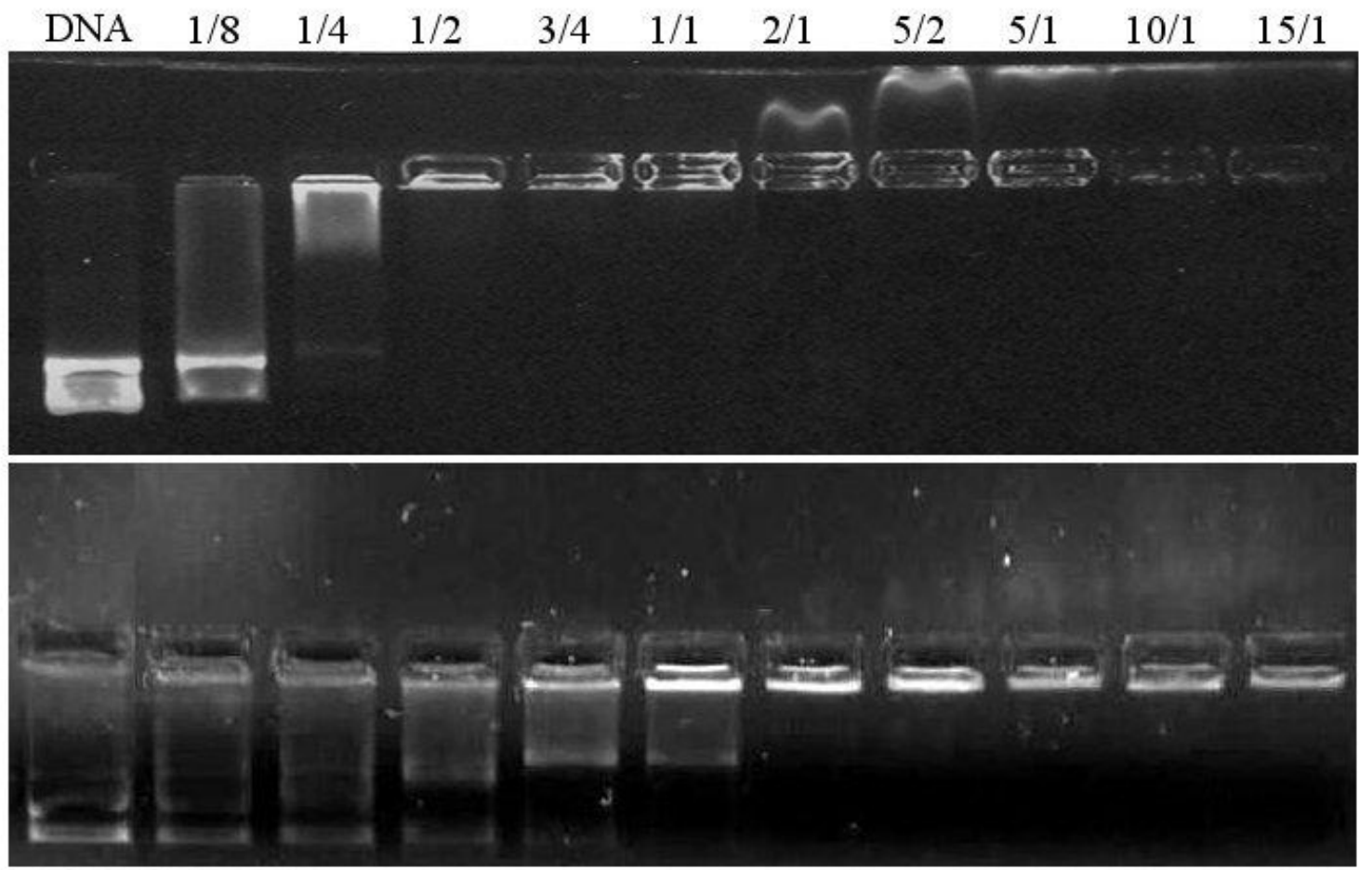

(b)
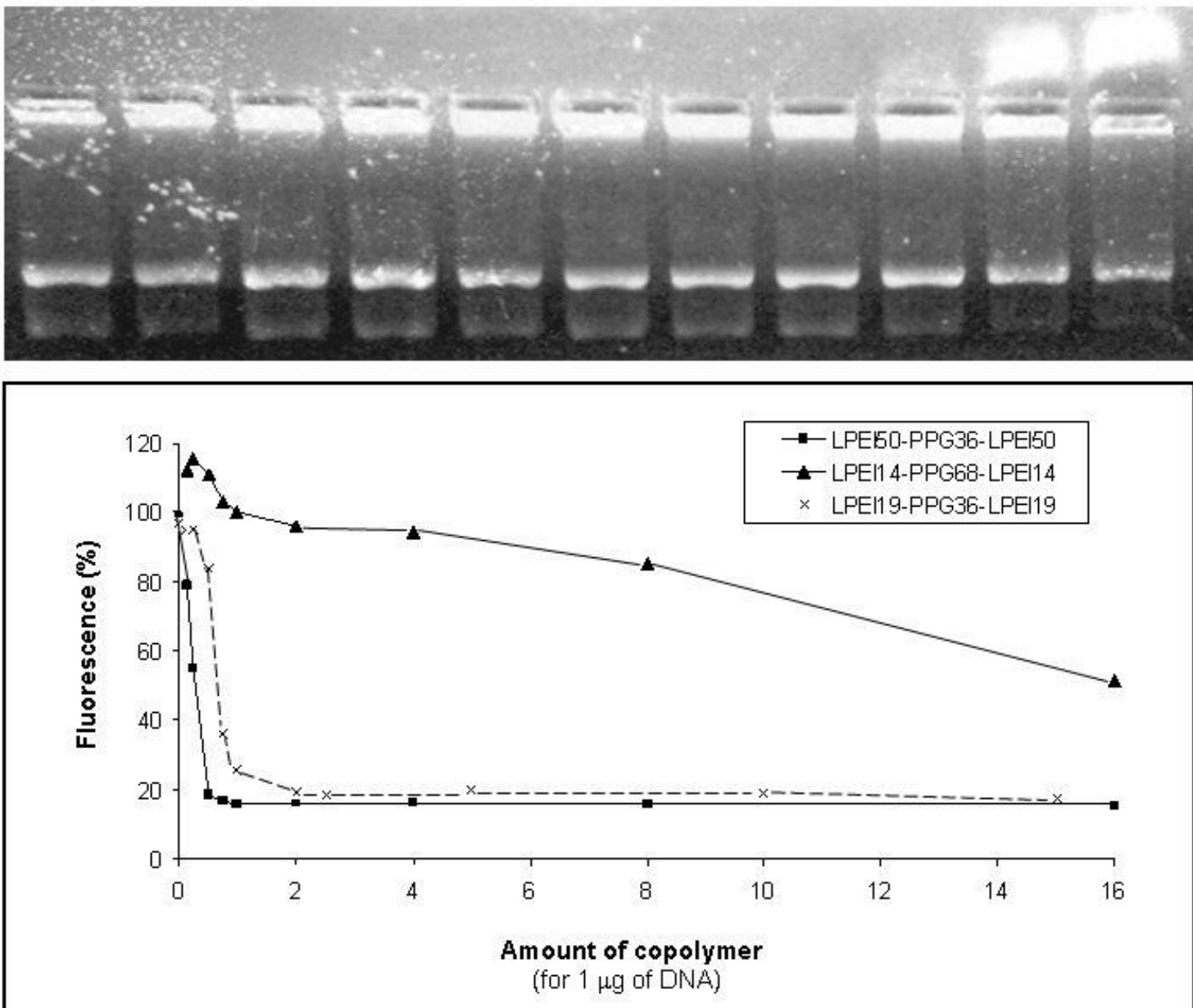
Figure 4:

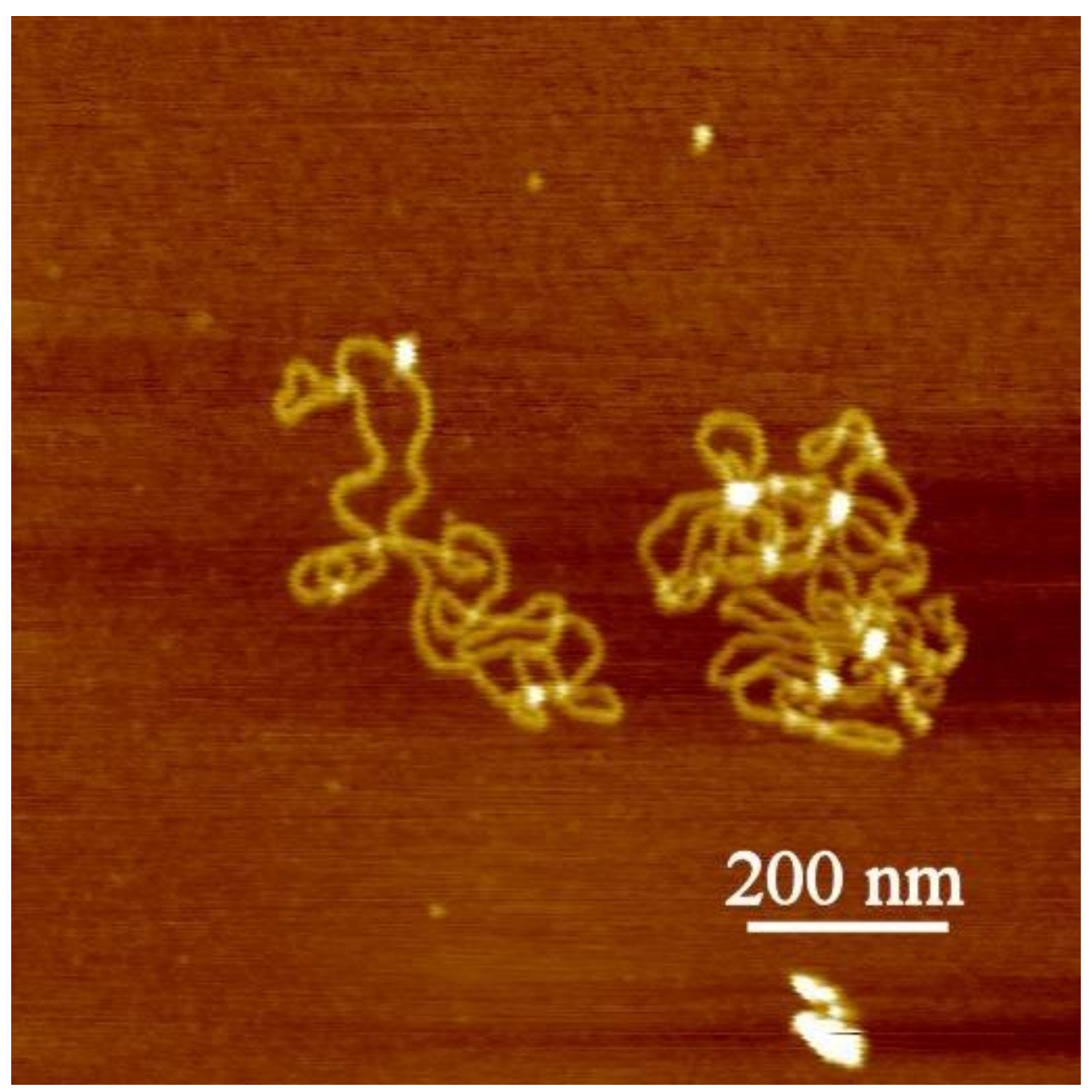


Figure 5

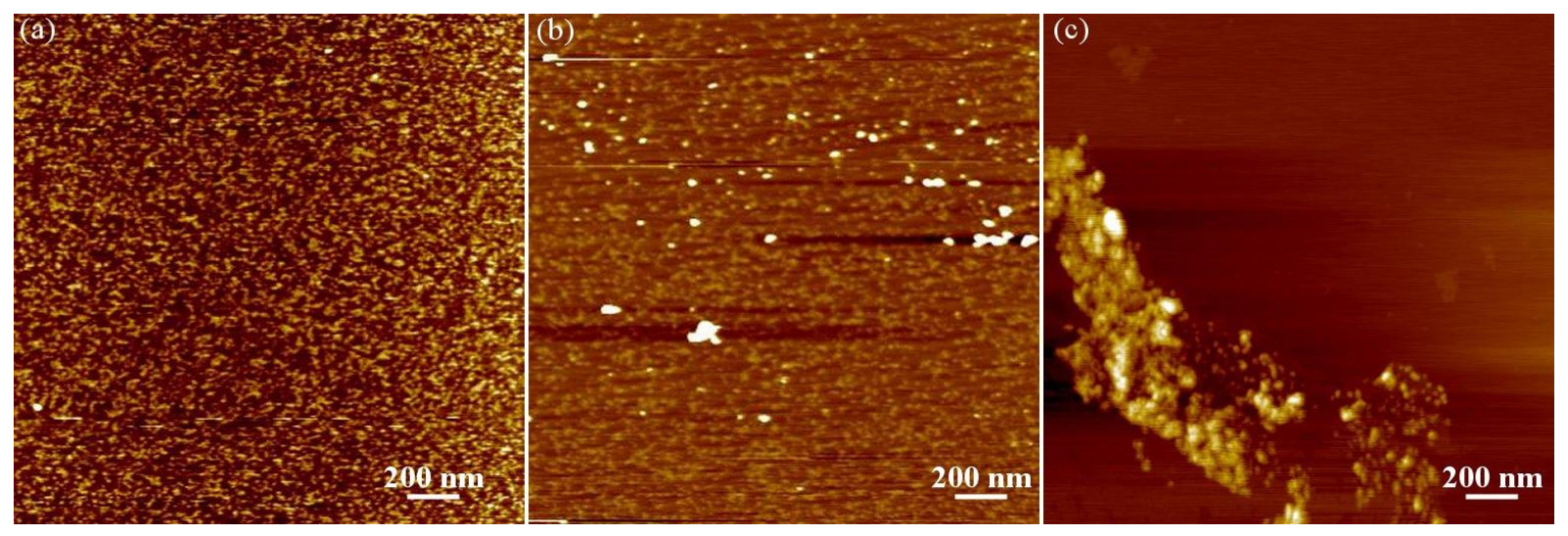


Figure 6

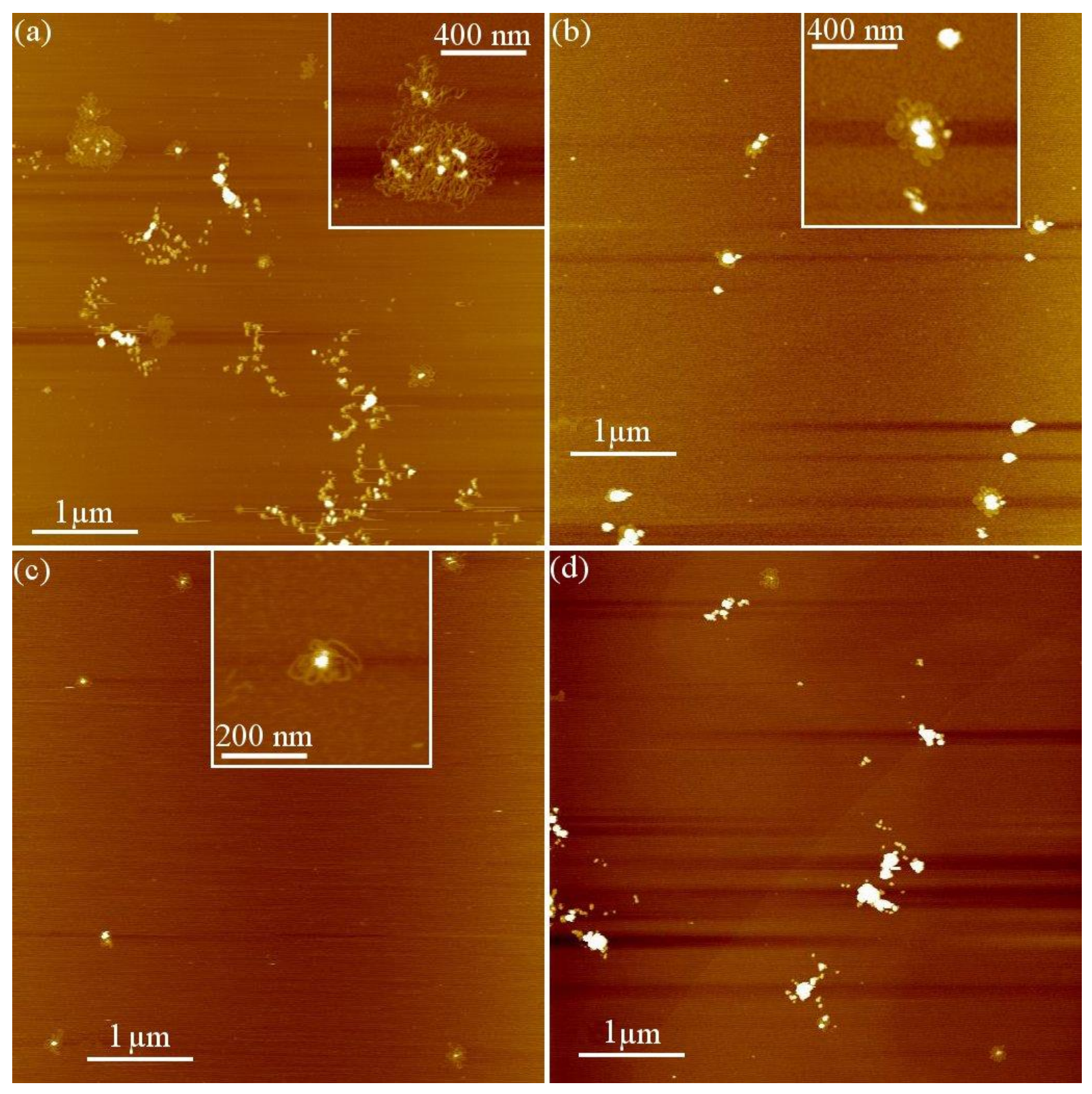


Figure 7
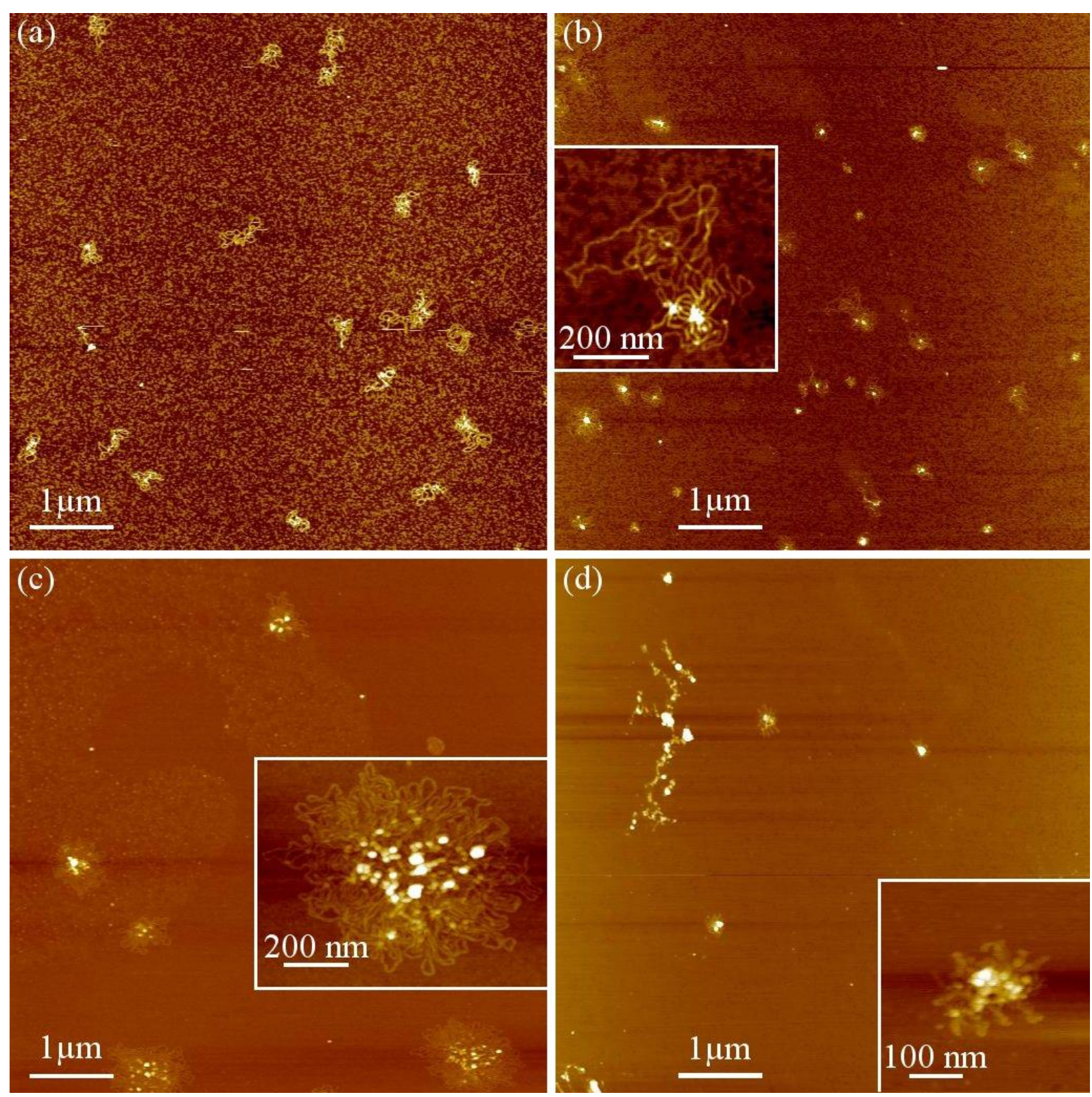
Figure 8

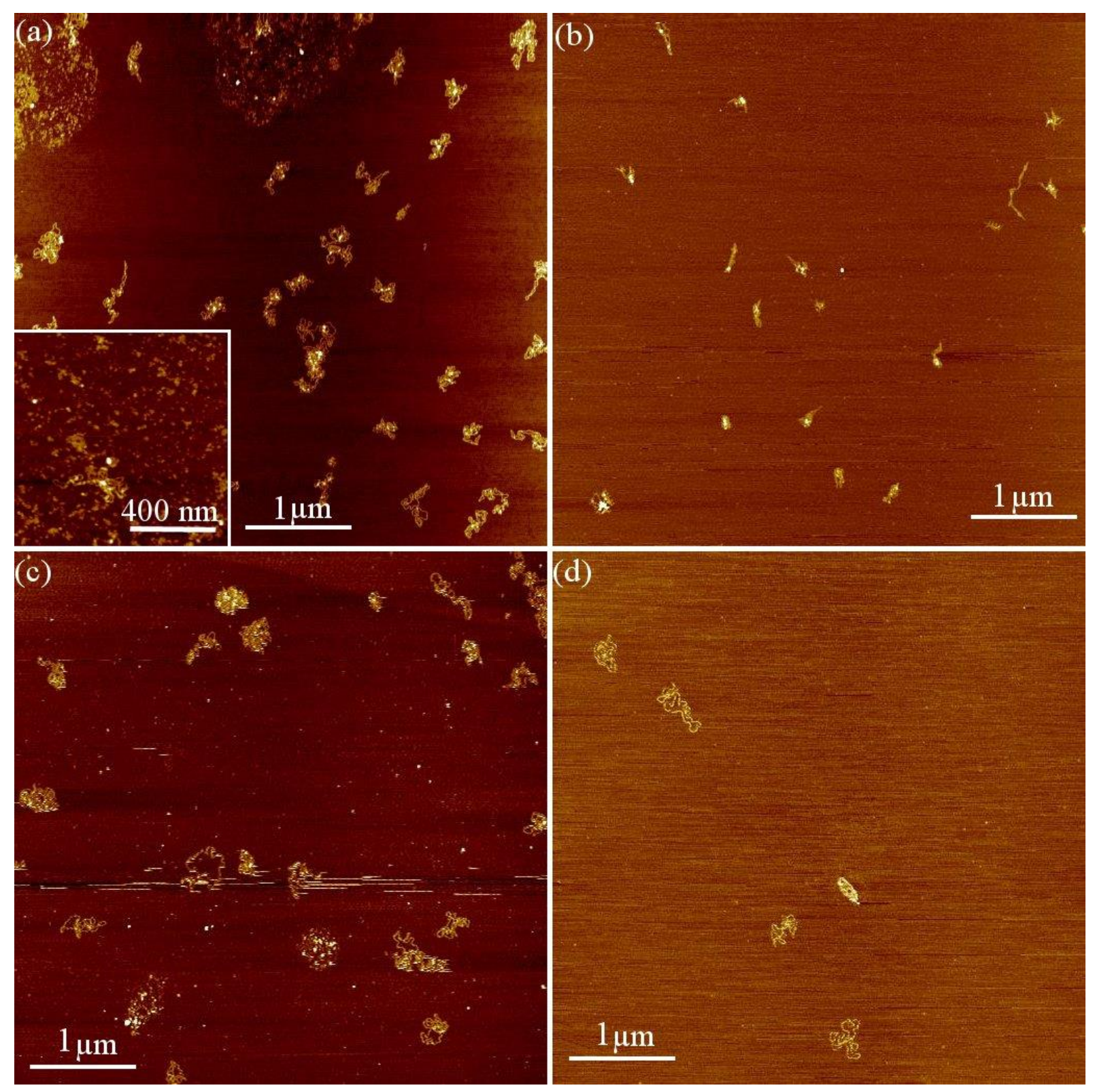




\section{References}

1 Li, S.-D.; Huang, L. Gene Therapy, 2006, 13, 1313.

2 Kundu, P. P.; Sharma, V. Curr. Op. Solid State and Mat. Sci 2008, 12, 89.

3 Neu, M.; Fischer, D.; Kissel, T. J. Gene Med 2005, 7, 992.

4 Büning, H.; Perabo, L.; Coutelle, O.; Quadt-Hummel, S.; Hallek, M. J. Gene Med. 2008, 10, 717.

5 Boussif, O.; Lezoualc'h, F.; Zanta, M. A.; Mergny, M. D.; Scherman, D.; Demeneix, B.; Behr, J. P. Proc Natl Acad Sci USA. 1995, 92, 7297.

6 Fischer, D.; Bieber, T.; Li, Y.; Elsässer, H.-P.; Kissel, T. Pharma. Research 1999, 16, 1273.

7 Zou S. M.; Erbacher P.; Remy J. S.; Behr J. P. J Gene Med. 2000, 2, 128.

8 Roques C.; Fattal E.; Fromes Y. J Gene Med. 2009, 11, 240.

9 Alimi-Guez D.; Leborgne C.; Pembouong G.; Van Wittenberghe L.; Mignet N.; Scherman D.; Kichler A. J Gene Med. 2009, 11, 1114.

10 Pitard B.; Pollard H.; Agbulut O.; Lambert O.; Vilquin J. T.; Cherel Y.; Abadie J.; Samuel J. L.; Rigaud J. L.; Menoret S.; Anegon I.; Escande D. Hum Gene Ther. 2002, 13, 1767.

11 Brissault, B.; Leborgne, C.; Scherman, D.; Guis, C.; Kichler, A. to be published, 2010.

12 Mann, A.; Khan, M. A.; Shukla, V.; Ganguli, M. Biophys. Chem. 2007, 129, 126.

13 Hou, S.; Yang, K.; Yao, Y.; Liu, Z.; Feng, X.; Wang, R.; Yang, Y.; Wang, C. 2008, Colloids Surf B Biointerfaces 2008, 62, 151.

14 Brissault B.; Kichler A.; Leborgne C.; Jarroux N.; Cheradame H.; Guis C. ChemMedChem 2007, 2, 1202. 
15 Pastré, D.; Piétrement, O.; Fusil, S.; Landousy, F.; Jeusset, J.; David, M. O.; Hamon, L.; Le Cam, E.; Zozime, A. Biophysical Journal, 2003, 85, 2507.

16 Hansma, H. G.; Revenk, I.; Kim, K.; Laney, D. E., Nucleic Acids Research, 1996, 24, 713.

17 Zipper, H.; Brunner, H.; Bernhagen, J.; Vitzthum, F. Nucleic Acids Research 2004, 32, e103.

18 Manning, G. S. J. of Chem. Phys. 1969, 54, 924.

19 Brissault, B.; Kichler, A.; Guis, C.; Leborgne, C.; Danos, O.; Cheradame, H.; Bioconjugate, 2003, 14, 581 .

20 Wilson, R. W.; Bloomfield, V. A. Biochemistry, 1979, 18, 2192. 